\title{
Front Matter: Volume 9000
}

, "Front Matter: Volume 9000," Proc. SPIE 9000, Laser Refrigeration of Solids VII, 900001 (17 March 2014); doi: 10.1117/12.2063512

SPIE. Event: SPIE OPTO, 2014, San Francisco, California, United States 


\section{PROCEEDINGS OF SPIE}

\section{Laser Refrigeration of Solids VII}

Richard I. Epstein

Denis V. Seletskiy

Mansoor Sheik-Bahae

Editors

5-6 February 2014

San Francisco, California, United States

Sponsored and Published by

SPIE 
The papers included in this volume were part of the technical conference cited on the cover and title page. Papers were selected and subject to review by the editors and conference program committee. Some conference presentations may not be available for publication. The papers published in these proceedings reflect the work and thoughts of the authors and are published herein as submitted. The publisher is not responsible for the validity of the information or for any outcomes resulting from reliance thereon.

Please use the following format to cite material from this book:

Author(s), "Title of Paper," in Laser Refrigeration of Solids VII, edited by Richard I. Epstein,

Denis V. Seletskiy, Mansoor Sheik-Bahae, Proceedings of SPIE Vol. 9000 (SPIE, Bellingham, WA, 2014) Article CID Number.

ISSN: 0277-786X

ISBN: 9780819499134

Published by

SPIE

P.O. Box 10, Bellingham, Washington 98227-0010 USA

Telephone +1 3606763290 (Pacific Time) · Fax +1 3606471445

SPIE.org

Copyright (C) 2014, Society of Photo-Optical Instrumentation Engineers.

Copying of material in this book for internal or personal use, or for the internal or personal use of specific clients, beyond the fair use provisions granted by the U.S. Copyright Law is authorized by SPIE subject to payment of copying fees. The Transactional Reporting Service base fee for this volume is $\$ 18.00$ per article (or portion thereof), which should be paid directly to the Copyright Clearance Center (CCC), 222 Rosewood Drive, Danvers, MA 01923. Payment may also be made electronically through CCC Online at copyright.com. Other copying for republication, resale, advertising or promotion, or any form of systematic or multiple reproduction of any material in this book is prohibited except with permission in writing from the publisher. The CCC fee code is 0277-786X/14/\$18.00.

Printed in the United States of America.

Publication of record for individual papers is online in the SPIE Digital Library.

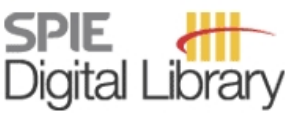

SPIEDigitalLibrary.org

Paper Numbering: Proceedings of SPIE follow an e-First publication model, with papers published first online and then in print and on CD-ROM. Papers are published as they are submitted and meet publication criteria. A unique, consistent, permanent citation identifier (CID) number is assigned to each article at the time of the first publication. Utilization of CIDs allows articles to be fully citable as soon as they are published online, and connects the same identifier to all online, print, and electronic versions of the publication. SPIE uses a six-digit CID article numbering system in which:

- The first four digits correspond to the SPIE volume number.

- The last two digits indicate publication order within the volume using a Base 36 numbering

system employing both numerals and letters. These two-number sets start with 00, 01, 02, 03, 04, $05,06,07,08,09,0 A, 0 B \ldots$. 0Z, followed by 10-1Z, 20-2Z, etc.

The CID Number appears on each page of the manuscript. The complete citation is used on the first page, and an abbreviated version on subsequent pages. Numbers in the index correspond to the last two digits of the six-digit CID Number. 


\section{Contents}

$\checkmark$ Conference Committee

\section{CRYOGENIC REFRIGERATION IN RARE-EARTH-DOPED SYSTEMS}

900002 Device applications of cryogenic optical refrigeration [9000-1]

S. D. Melgaard, The Univ. of New Mexico (United States) and Air Force Research Lab. (United States); D. V. Seletskiy, Univ. of Konstanz (Germany); R. I. Epstein, The Univ. of New Mexico (United States) and ThermoDynamic Films (United States); J. V. Alden,

ThermoDynamic Films (United States); M. Sheik-Bahae, The Univ. of New Mexico (United States)

900003 Effect of impurities on cooling efficiency in fluoride crystals (Invited Paper) [9000-2] A. Di Lieto, Univ. di Pisa (Italy) and Lab. NEST, Istituto Nanoscienze, CNR (Italy); A. Sottile, A. Volpi, Z. Zhang, Univ. di Pisa (Italy); M. Tonelli, Univ. di Pisa (Italy) and Lab. NEST, Istituto Nanoscienze, CNR (Italy)

900004 Preparation of high-purity LiF, $\mathrm{YF}_{3}$, and $\mathrm{YbF}_{3}$ for laser refrigeration (Invited Paper) [9000-3] M. P. Hehlen, W. L. Boncher, Los Alamos National Lab. (United States); S. D. Melgaard, Air Force Research Lab. (United States); M. W. Blair, Los Alamos National Lab. (United States); R. A. Jackson, T. E. Littleford, Keele Univ. (United Kingdom); S. P. Love, Los Alamos National Lab. (United States)

900005 Intracavity optical refrigeration to $131 \mathrm{~K}$ using high-power vertical external-cavity surface-emitting lasers (VECSELs) [9000-4]

M. Ghasemkhani, A. R. Albrecht, The Univ. of New Mexico (United States); S. D. Melgaard, The Univ. of New Mexico (United States) and Air Force Research Lab. (United States);

D. V. Seletskiy, The Univ. of New Mexico (United States) and Univ. of Konstanz (Germany); J. G. Cedeberg, Sandia National Labs. (United States); M. Sheik-Bahae, The Univ. of New Mexico (United States)

\section{NOVEL COOLING CONCEPTS}

$900006 \quad p \times n$-type transverse thermoelectrics: an alternative Peltier refrigerator with cryogenic promise (Invited Paper) [9000-5]

C. Zhou, Y. Tang, M. Grayson, Northwestern Univ. (United States)

$90000 \mathrm{~A} \quad$ Laser cooling of dense atomic gases by collisional redistribution of radiation and spectroscopy of molecular dimers in a dense buffer gas environment [9000-9] A. Saß, R. Forge, S. Christopoulos, K. Knicker, P. Moroshkin, M. Weitz, Rheinische FriedrichWilhelms-Univ. Bonn (Germany) 
900006 Optical cooling in multi-level systems (Invited Paper) [9000-15]

S. R. Bowman, U.S. Naval Research Lab. (United States); J. Ganem, Loyola Univ. Maryland (United States); C. G. Brown, SOTERA Defense Solutions, Inc. (United States)

$9000 \mathrm{OH}$ Temperature dynamics of laser cooling of solids with $\mathrm{Yb}^{3+}$ ions [9000-16]

G. Nemova, R. Kashyap, Ecole Polytechnique de Montréal (Canada)

9000 Ol Direct measurement of laser cooling of Yb:YAG crystal at atmospheric pressure using a fiber Bragg grating [9000-17]

E. Soares de Lima Filho, G. Nemova, S. Loranger, R. Kashyap, Ecole Polytechnique de Montréal (Canada)

\section{APPLICATIONS AND DEVICE CONCEPTS}

$9000 \mathrm{OM}$ Exploring Coulomb interaction in piezoelectric materials for assisting the laser cooling of solids [9000-26]

I. Hassani Nia, H. Mohseni, Northwestern Univ. (United States)

9000 ON Upconversion lasing, heat transfer and stimulated cooling in solids [9000-27]

K. Sandner, H. Ritsch, Univ. of Innsbruck (Austria)

\section{POSTER SESSION}

900000 Spectroscopic evaluation of Tm-doped potassium lead halides for $2 \mu \mathrm{m}$ laser cooling applications [9000-23]

E. Kumi-Barimah, U. Hömmerich, E. E. Brown, Hampton Univ. (United States); S. B. Trivedi, Brimrose Corp. of America (United States)

$9000 \mathrm{OP}$ Light up conversion versus light down conversion in radiative cooling of semiconductors [9000-24]

V. K. Malyutenko, V. E. Lashkaryov Institute of Semiconductor Physics (Ukraine)

Author Index

iv 


\section{Conference Committee}

Symposium Chairs

David L. Andrews, University of East Anglia Norwich (United Kingdom)

Alexei L. Glebov, OptiGrate Corporation (United States)

Symposium Co-chairs

Jean Emmanuel Broquin, IMEP-LAHC (France)

Shibin Jiang, AdValue Photonics, Inc. (United States)

Program Track Chair

Zameer U. Hasan, Temple University (United States)

Conference Chairs

Richard I. Epstein, The University of New Mexico (United States)

Denis V. Seletskiy, University Konstanz (Germany)

Mansoor Sheik-Bahae, The University of New Mexico (United States)

Conference Program Committee

Daniel A. Bender, Sandia National Laboratories (United States)

Steven R. Bowman, U.S. Naval Research Laboratory (United States)

Tal Eliezer Carmon, University of Michigan (United States)

Joaquín Fernández, Universidad del País Vasco (Spain)

Zameer U. Hasan, Temple University (United States)

Raman Kashyap, Ecole Polytechnique de Montréal (Canada)

Mauro Tonelli, Universita di Pisa (Italy)

Qihua Xiong, Nanyang Technological University (Singapore)

Paul D. LeVan, Air Force Research Laboratory (United States)

\section{Session Chairs}

1 Cryogenic Refrigeration in Rare-Earth-doped Systems

Raman Kashyap, Ecole Polytechnique de Montréal (Canada)

2 Novel Cooling Concepts

Qihua Xiong, Nanyang Technological University (Singapore)

3 Laser Cooling in Semiconductors

Daniel A. Bender, Sandia National Laboratories (United States) 
$4 \quad$ Novel Rare-Earth-doped Systems

Markus P. Hehlen, Los Alamos National Laboratory (United States)

5 Applications and Device Concepts

Steven R. Bowman, U.S. Naval Research Laboratory (United States)

Proc. of SPIE Vol. $9000900001-6$

Downloaded From: https://www.spiedigitallibrary.org/conference-proceedings-of-spie on 26 Apr 2023 Terms of Use: https://www.spiedigitallibrary.org/terms-of-use 